\title{
URGENSI JAMINAN DALAM PRODUK PEMBIAYAAN DI PERBANKAN SYARI'AH
}

\begin{abstract}
Jamaluddin $^{*}$
Abstrak

Dalam perbankan syari'ah secara umum jaminan dibagi menjadi dua: jaminan yang berupa orang (personal guaranty) dan jaminan yang berupa harta benda. Yang pertama sering dikenal dengan istilah dlaman atau kafalah. Sedangkan yang kedua dikenal dengan istilah rahn. Kafalah adalah Jaminan yang diberikan oleh kafil (penanggung) kepada pihak ketiga atas kewajiban (prestasi) yang harus ditunaikan pihak kedua (tertanggung). Al-rahn adalah harta yang dijadikan pemiliknya sebagai jaminan utang yang bersifat mengikat. Jaminan sangat menentukan tingkat keamanan pembiayaan yang disalurkan oleh bank. Di samping itu, keberadaan agunan menjadi sangat penting, dan hal ini berhubungan dengan filosofi dasar dari dana bank. Atas dasar beberapa pertimbangan di atas, maka pengajuan pembiayaan di bank syari'ah yang menggunakan skim musyarakah ataupun mudharahah dikenakan kewajiban memberikan agunan.
\end{abstract}

Kata Kunci: Jaminan, Pembiayaan, Bank Syariah

\section{Pendahuluan}

Undang-undang (UU) Perbankan Syari'ah telah ditetapkan pada tanggal 18 Juni 2008, kini Perbankan Syari'ah telah mendapatkan payung hukum tertinggi yang akan melindungi kiprah dan sepak terjang perbankan syari'ah dalam industri keuangan syari'ah di tanah air. Undang-undang Perbankan Syari'ah (UUPS) adalah kristalisasi dari sebuah perjuangan umat Islam Indonesia yang cukup panjang dalam rangka menerapkan prinsip-prinsip syari'ah di bidang mu'amalah, khususnya mu'amalah maliyah. Namun harus diingat bahwa Undangundang Perbankan Syari'ah (UUPS) ini jangan hanya menjadi simbol legalitas yang kosong akan nilai subtansi dan makna positifnya.

Undang-undang Perbankan Syari'ah (UUPS) harus dipersepsikan sebagai suatu payung besar legalitas tertinggi yang tidak saja mampu mempercepat pertumbuhan perbankan syari'ah di tanah air,

* Institut Agama Islam Tribakti (IAIT) Kediri 
tetapi juga memberikan konstribusi positif dalam mendongkrak laju pertumbuhan ekonomi nasional yaang berkeadilan rakyat dan berorientasi kepada pemerataan (aquility) dan sektor riil. Sebagai lembaga intermedia keuangan, bank syariah memiliki kegiatan utama berupa penghimpunan dana dari masyarakat melalui simpanan dalam bentuk giro, tabungan, dan deposito yang menggunakan prinsip wadia'ah yad al-dlamanah (titipan), dan mudharabah (investasi bagi hasil).

Bank Syari'ah menyalurkan kembali dana tersebut kepada masyarakat umum dalam berbagai bentuk skim, seperti skim jual beli (al-ba'i), murabahah, salam, istishna, sewa (ijarah), dan bagi hasil (masyarakah dan mudharabah), serta produk pelengkap lainnya, yaitu fee based service, hiwalah (alih utang piutang), rahn (gadai), qardh (utang piutang), wakalah (perwakilan, agency), kafalah (garansi bank). ${ }^{1}$ Dalam hal ini masyarakat menyerahkan dananya pada bank syari'ah pada dasarnya tanpa jaminan yang bersifat kebendaan dan semata-mata hanya dilandasi oleh kepercayaan bahwa pada waktunya dana tersebut akan kembali ditambah dengan sejumlah keuntungan (return). Oleh karena itu untuk menjaga kepercayaan masyarakat tersebut, bank harus melaksanakan prinsip kehati-hatian (prudential).

Berdasarkan prinsip tersebut, bank syari'ah menerapkan sistem analisa yang ketat dalam penyaluran dananya melalui pembiayaan, di antaranya dengan mempersyaratkan adanya jaminan bagi pihak nasabah yang hendak mengajukan pembiayaan, termasuk pembiayaan yang menggunakan akad mudharabah. Permasalahan yang muncul adalah dapatkah perbankan mengenakan jaminan untuk akad mudharabah yang nota bene merupakan akad kepercayaan (amanah) dan bagaimana konsep jaminan menurut hukum Islam serta aplikasinya di perbankan syari'ah, khususnya di Indonesia.

\section{Konsep Jaminan dalam Hukum Islam}

Secara umum jaminan dalam hukum Islam (fiqh) dibagi menjadi dua: jaminan yang berupa orang (personal guaranty) dan jaminan yang berupa harta benda. Yang pertama sering dikenal dengan istilah dlaman atau kafalah. Sedangkan yang kedua dikenal dengan istilah rahn. Oleh karena itu pembahasan berikut akan mengulas kedua macam istilah tersebut menurut hukum Islam.

1 Widjanato, Hukum dan Ketentuan Perbankan di Indonesia, edisi Iv, (Jakarta: Pustaka Utama Grafiti, 2003), h.59-61 
Jaminan menurut UU. No. 10 Tahun 1998 tentang Perbankan adalah keyakinan atas kesanggupan nasabah debitur untuk melunasi kewajibannya sesuai dengan yang diperjanjikan. Jaminan di sini meliputi watak, kemampuan, modal, agunan, dan prospek usaha dari Nasabah Debitur. Sedangkan dalam makalah ini jaminan identik dengan agunan yaitu Jaminan tambahan yang diserahkan nasabah debitur kepada bank dalam rangka pemberian fasilitas kredit atau pembiayaan berdasarkan prinsip syari'ah. (pasal 1 angka 23 UU No. 10 Tahun 1998).

\section{Kafalah}

Kafalah menurut etimologi berarti al-dhamanah, hamalah, dan za'amah, ketiga istilah tersebut memiliki arti yang sama, yakni menjamin atau menanggung. ${ }^{2}$ Sedangkan menurut terminologi kafalah adalah "Jaminan yang diberikan oleh kafil (penanggung) kepada pihak ketiga atas kewajiban (prestasi) yang harus ditunaikan pihak kedua (tertanggung)".

Kafalah diisyaratkan oleh Allah SWT. pada Al-Qur'an Surat Yusuf, 72; "penyeru-penyeru itu berkata: "Kami kehilangan piala Raja, dan siapa yang dapat mengembalikannya akan memperoleh bahan makanan (seberat) beban unta, dan aku menjamin terhadapnya". Dalam hadis Nabi saw; "Pinjaman hendaklah dikembalikan dan yang menjamin hendaklah membayar" (H.R. Abu Dawud).

Kafalah dinilai sah menurut hukum Islam apabila memenuhi rukun dan syaratnya, yaitu:

1. Kafil (orang yang menjamin), disyaratkan sudah baligh, berakal, tidak dicegah membelanjakan harta (mahjur) dan dilakukan dengan kehendaknya sendiri.

2. Makfullah (orang yang berpiutang/berhak menerima jaminan), syaratnya ialah diketahui oleh orang yang menjamin, ridha (menerima), dan ada ketika terjadinya akad menjaminan.

3. Makful 'anhu (orang yang berutang/yang dijamin), disyaratkan diketahui oleh yang menjamin, dan masih hidup (belum mati).

4. Madmun bih atau makful bih (hutang/kewajiban yang dijamin), disyaratkan merupakan hutang/prestasi yang harus dibayar atau dipenuhi, menjadi tanggungannya (makful anhu), dan bisa diserahkan oleh penjamin (kafil).

\footnotetext{
${ }^{2}$ Wahbah Zuhaili, Al-Fiqh al-Islamy wa Adillatuhu, ( Beirut: Dar al-Fikr, 2002),
} cet. 6, h. 4141 . 
5. Lafadz ijab qabul, disyaratkan keadaan lafadz itu berarti menjamin, tidak digantungkan kepada sesuatu dan tidak berarti sementara. ${ }^{3}$

Kafalah dibagi menjadi dua macam, yaitu kafalah dengan jiwa (kafalah bi al-nafs) dan kafalah dengan harta (kafalah bi al-maal). Kafalah dengan jiwa dikenal pula dengan Kafalah bi al-Wajhi, yaitu adanya kesediaan pihak penjamin (al-Kafil, al-Dhamin atau al-Za'im) untuk menghadirkan orang yang ia tanggung kepada yang ia janjikan tanggungan (Makful lah).

Kafalah yang kedua ialah kafalah harta, yaitu kewajiban yang mesti ditunaikan oleh dhamin atau kafil dengan pembayaran (pemenuhan) berupa harta. Kafalah harta ada tiga macam, yaitu: pertama, kafalah bi al-Dayn, yaitu kewajiban membayar hutang yang menjadi beban orang lain. kedua, kafalah dengan penyerahan benda, yaitu kewajiban menyerahkan benda-benda tertentu yang ada ditangan orang lain, seperti mengembalikan barang yang di-ghashab dan menyerahkan barang jualan kepada pembeli. Ketiga, kafalah dengan 'aib, maksudnya adalah jaminan bahwa jika barang yang dijual ternyata mengandung cacat, karena waktu yang terlalu lama atau karena hal-hal lainnya, maka penjamin (pembawa barang) bersedia memberi jaminan kepada penjual untuk memenuhi kepentingan pembeli (mengganti barang yang cacat tersebut).

\section{Rahn}

Secara etimologi, kata al-rahn berarti tetap, kekal, dan jaminan. Akad al-rahn dalam istilah hukum positif disebut dengan barang jaminan (agunan). Sedangkan menurut istilah al-rahn adalah "harta yang dijadikan pemiliknya sebagai jaminan utang yang bersifat mengikat."

Berdasarkan definisi yang berasal dari ulama madzhab Maliki tersebut, obyek jaminan dapat berbentuk materi, atau manfaat, dimana keduanya merupakan harta menurut jumhur ulama. Benda yang dijadikan barang jaminan (agunan) tidak harus diserahkan secara aktual, tetapi boleh juga penyerahannya secara hukum, seperti menjadikan sawah sebagai jaminan (agunan), sehingga yang diserahkan adalah surat jaminannya (sertifikat sawah). ${ }^{5}$ Berbeda dengan definisi di atas, menurut ulama Syafi'iyah dan Hanabilah, al-rahn adalah "menjadikan materi (barang) sebagai jaminan utang, yang dapat dijadikan pembayar

\footnotetext{
${ }^{3}$ Wahbah Zuhaili, Al-Figh al-Islamy wa Adillatuhu , h. 4152-4161.

${ }^{4}$ Ad-Dardir, Syarh al-Shagir bi Syarb ash-Sha-wi, (Mesir: Dar al-Fikr, 1978),
} Jilid III, h. 303.

${ }^{5}$ Ad-Dardir, Syarh al-Shagir bi Syarb ash-Sha-wi. h. 325. 
utang apabila orang yang berutang tidak bisa membayar utangnya itu." 6 Definisi ini mengandung pengertian bahwa barang yang boleh dijadikan jaminan (agunan) utang itu hanya yang bersifat materi; tidak termasuk manfaat sebagaimana yang dikemukakan ulama madzhab Maliki. Barang jaminan itu boleh dijual apabila utang tidak dapat dilunasi dalam waktu yang disepakati kedua belah pihak.

Para ulama fiqh mengemukakan bahwa akad al-rahn dibolehkan dalam Islam berdasarkan al-Qur'an dan sunnah Rasul. ${ }^{7}$ Dalam surat alBaqarah, 283:

Jika kamu dalam perjalanan (dan bermu'amalah tidak secara tunai) sedang kamu tidak memperoleh seorang penulis, Maka hendaklah ada barang tanggungan yang dipegang (oleh yang berpiutang). akan tetapi jika sebagian kamu mempercayai sebagian yang lain, Maka hendaklah yang dipercayai itu menunaikan amanatnya (hutangnya) dan hendaklah ia bertakwa kepada Allah Tuhannya; dan janganlah kamu (para saksi) Menyembunyikan persaksian. dan Barangsiapa yang menyembunyikannya, Maka Sesungguhnya ia adalah orang yang berdosa hatinya; dan Allah Maha mengetahui apa yang kamu kerjakan.

Rahn dinilai sah menurut hukum Islam, apabila telah memenuhi rukun dan syarat sebagai berikut:

a. Syarat yang terkait dengan orang yang berakad adalah cakap bertindak hukum. Kecakapan bertindak hukum, menurut jumhur ulama adalah orang yang telah baligh dan berakal. Sedangkan menurut ulama Hanafiyah, kedua belah pihak yang berakad tidak disyaratkan baligh tetapi cukup berakal saja. Oleh sebab itu menurut mereka anak kecil yang mumayyiz boleh melakukan akad rahn, dengan syarat akad al-rahn yang dilakukan anak kecil yang sudah mumayyiz ini mendapatkan persetujuan dari walinya.

b. Syarat shigat (lafal). Ulama Hanafiyah mengatakan dalam akad itu al-rahn tidak dikaitkan dengan syarat tertentu atau dikaitkan dengan masa yang akan datang karena al-rahn sama dengan akad jual beli. Apabila akad itu didasarkan pada syarat tertentu atau dikaitkan dengan masa yang akan datang, maka syaratnya batal, sedangkan akadnya sah. Ulama Malikiyah, Syafi'iyah dan Hanabilah mengatakan apabila syarat itu adalah syarat yang mendukung kelancaran akad itu, maka syarat itu diperbolehkan, tetapi apabila syarat itu bertentangan dengan tabiat akad al-rahn maka syaratnya

\footnotetext{
${ }^{6}$ Ibnu 'Abidin, Radd al-Muhktar 'ala ad-Durr al-Mukhtar, (Beirut: Dar alFikr, 1963), Jilid V, h. 339,

7 Asy-Syarbaini al-Khatib, Mugbni al-Muhtaj, (Beirut: Dar al-Fikr, 1994), Jilid II, h. 121, dan Ibnu Qudamah, al-Mughni, (Riyadh: Maktabah al-Haditsah, t.th.), Jilid IV, h. 226.
} 
batal. Kedua syarat dalam contoh di atas (perpanjangan al-rahn satu bulan dan agunan boleh dimanfaatkan), termasuk syarat yang tidak sesuai dengan tabiat al-rahn, karenanya syarat itu dinyatakan batal.

c. Syarat al-marhum bibi (utang) adalah: (1) merupakan hak yang wajib dikembalikan kepada orang tempat berutang. (2) Utang itu boleh dilunasi dengan agunan itu. (3) Utang itu jelas dan tertentu

d. Syarat al-marhun (barang yang dijadikan agunan), menurut para pakar fiqh, adalah: (1) barang jaminan (agunan) itu boleh dijual dan nilainya seimbang dengan utang, (2) barang jaminan itu bernilai dan dapat dimanfaatkan, (3) barang jaminan itu jelas dan tertentu, (4) agunan itu milik sah orang yang berutang, (5) barang jaminan itu tidak terkait dengan hak orang lain, (6) barang jaminan itu merupakan harta yang utuh, tidak bertebaran dalam beberapa tempat, dan (7) barang jaminan itu boleh diserahkan baik materinya maupun manfaatnya. ${ }^{8}$

Di samping syarat-syarat di atas, para ulama fiqh sepakat menyatakan bahwa al-rahn itu baru dianggap sempurna apabila barang yang dirahn-lian itu secara hukum sudah berada di tangan pemberi utang, dan uang yang dibutuhkan telah diterima peminjam uang. Apabila barang jaminan itu berupa benda tidak bergerak, seperti rumah dan tanah, cukup surat jaminan tanah atau surat-surat rumah itu yang dipegang oleh pemberi utang. Syarat yang terakhir (kesempurnaan alrahn) oleh para ulama disebut sebagai qabdh al-marhun (barang jaminan dikuasai secara hukum). Syarat ini menjadi penting karena dalam surat al-Baqarah, 2: 283 dinyatakan "fa rihanun magbudhati" (barang jaminan itu dikuasai secara hukum). ${ }^{9}$

Sebagai perbandingan, dalam sistem yang berlaku di Indonesia jaminan digolongkan menjadi 2 macam, yaitu jaminan materiil (kebendaan), dan jaminan imateriil (perorangan, borgtocht). Jaminan kebendaan mempunyai ciri-ciri "kebendaan" dalam arti memberikan hak mendahului di atas benda-benda tertentu dan mempunyai sifat melekat dan mengikuti benda yang bersangkutan. Sedangkan jaminan perorangan tidak memberikan hak mendahului atas benda-benda tertentu, tetapi hanya dijamin oleh harta kekayaan seorang lewat orang yang menjamin pemenuhan perikatan yang bersangkutan. ${ }^{10}$

${ }^{8}$ Imam al-Kasani, Bada'i al-Shana'i fi Tartib al-Syara'i, (Kairo: t.pn, 1969), Jilid VI, h. 125

${ }^{9}$ Ibn Rusyd, Bidayatul Mujtabid Wa Nibayatul Muqtashid, II,(Bairut: t.th.) h. 26

${ }^{10}$ Salim HS, Perkembangan Hukum Jaminan di Indonesia, (Jakarta:Rajawali Press, 2004), cet. 1, h.23. 


\section{Urgensi Jaminan Dalam Produk Pembiayaan Syari'ah}

Berbeda dengan perbankan konvensional yang dalam penyaluran dananya menggunakan istilah kredit, di perbankan syari'ah penyaluran dana menggunakan istilah pembiayaan. Pembiayaan adakalanya dengan mengambil keuntungan berdasarkan margin keuntungan (profit margin), seperti dalam akad jual beli murabahah, salam, istishna dan ijarah, juga dikenal pembiayaan yang menggunakan prinsip bagi hasil, yaitu melalui akad musyarakah dan mudharabah. Kedua akad pembiayaan ini dilihat dari ciri khasnya sangat berbeda sekali dengan akad yang lain. Di antara perbedaan menonjol adalah bahwa bank syari'ah dalam penyaluran dananya kepada nasabah penerima pembiayaan tidak dapat dipastikan memperoleh keuntungan tertentu (modal pembiayaan ditambah return) sebagaimana dalam skim pembiayaan yang mengambil keuntungan berdasarkan margin keuntungan. Akan tetapi, justru pihak bank sangat memungkinkan mengalami kerugian bila usaha nasabahnya mengalami kegagalan atau kebangkurutan, inilah konsekuensi dari skim pembiayaan dengan prinsip bagi hasil (profit and loss sharing). Namun, sebaliknya bila usaha nasabah berhasil maka akan memperoleh bagi hasil yang mungkin lebih besar bila dibandingkan penyaluran dana melalui skim pembiayaan berdasarkan margin keuntungan, ini karena di antara kedua pihak (bank dan nasabah) telah ada kesepakatan bagi hasilnya, yang biasanya berkisar 30\%:70\%, 40\%:60\%, atau 50\%:50\%.

Atas dasar tingkat spekulasi yang tinggi dalam skim pembiayaan, maka umumnya bank syari'ah sangat berhati-hati dalam melakukan penyaluran dana melalui skim ini. Apalagi kalau mengingat bahwa bank syari'ah sebagaimana bank konvensional merupakan lembaga intemediary keuangan. Di mana dana yang dikelola oleh bank sebagian besar merupakan dana pihak ketiga (nasabah kreditur) baik yang berupa dana tabungan (titipan/wadi'ah) maupun dana investasi yang berupa deposito (mudharabah atau musyarakah). Dan sebagaimana lazimnya bahwa dana nasabah tersebut sewaktu-waktu atau dalam jangka waktu tertentu akan diambil kembali oleh nasabah dengan tambahan keuntungan baik yang berupa bagi hasil (bila berupa dana investasi) atau bonus (bila berupa dana titipan).

Sebagai wujud sikap kehati-hatian bank dalam melakukan penyaluran dananya melalui skim pembiayaan melalui bagi hasil ini, sebelum memberikan kredit atau pembiayaan, bank syari'ah harus melakukan penilaian yang seksama terhadap watak, kemampuan, modal, agunan, dan prospek usaha dari Nasabah Debitur. Kelima unsur 
tersebut yang sering disebut 5C perkreditan (Character, Capital, Capacity, Collateral dan Condition of Economy). Memang secara teoritis bahwa yang terpenting pertama-pertama adalah karakter dari nasabah calon penerima pembiayaan inasabah debitur), karena jika karakternya baik, sekalipun kondisi yang lainnya buruk, nasabah debitur akan tetap berusaha serius dan dengan jujur melaporkan hasil usahanya dengan mengembalikan dana pembiayaan yang disertai bagi hasilnya. Namun, tidak dapat dipungkiri bahwa pada kenyataannya jaminan sangat menentukan tingkat keamanan pembiayaan yang disalurkan oleh bank. Di samping itu, Keberadaan agunan menjadi sangat penting, dan hal ini berhubungan dengan filosofi dasar dari dana bank sebagaimana disinggung di atas, yaitu bahwa dana bank adalah dana nasabah atau masyarakat yang harus dilindungi dan digunakan secara sangat hati-hati.

Atas dasar beberapa pertimbangan di atas, maka pengajuan pembiayaan di bank syari'ah yang menggunakan skim musyarakah ataupun mudharahah dikenakan kewajiban memberikan anggunan. Padahal secara teoritis, pengenaan kewajiban memberikan anggunan kepada nasabah debitur untuk skim/akad musyarakah dan mudharahah bertentangan dengan prinsip dasar kedua akad tersebut, vang dalam hukum Islam dikenal dengan akad kepercayaan (amanah). Pembahasan tentang status akad amanah dalam skim pembiayaan terutama melalui akad mudharahah di perbankan syari'ah akan dibahas dalam sub bab berikutnya.

Kenyataan di atas, meskipun masih menyimpan persoalan status hukumnya dari sisi hukum Islam, menunjukkan bahwa jaminan mutlak diperlukan untuk memberikan kepastian bahwa dana tersebut dapat dikembalikan, atau setidaknya bank tidak akan mengalami kerugian yang terlalu besar, jika misalnya ternyata hanya dapat mengeksekusi agunan atau jaminan yang telah diberikan, karena debitur bertindak semaunya atau asal-asalan dalam menjalankan usaha bisnisnya.

Dalam hukum positif Indonesia terdapat berbagai peraturan perundang-undangan yang mengatur jaminan dalam rangka melaksanakan sistem kehati-hatian (prudential) yang harus dilakukan oleh indutri perbankan, termasuk perbankan syari'ah. Peraturan perundang-undangan tersebut antara lain dapat dilihat dalam ketentuanketentuan UU No. 7 Tahun 1992 tentang Perbankan, yang telah diubah dengan UU No. 10 tahun 1998, peraturan perundang-undangan Bank Indonesia dan KUH Perdata. Berikut akan disebutkan beberapa pasal perundang-undangan di atas yang terkait dengan urgensitas jaminan di perbankan: 
a. Dalam UU No. 10 tahun 1998 terdapat pada pasal pasal 8, dan penjelasanya pasal 8 ayat (1) serta pasal 12 A ayat (1) berikut ini: "...Dalam memberikan kredit atau pemhiayaan berdasarkan prinsip syari'ab, Bank umum wajib mempunyai keyakinan berdasarkan analisis yang mendalam atau itikad baik dan kemampuan serta kesanggupan debitur untuk melunasi hutangnya atau dimaksud sesuai dengan yang mengembalikan pembiayaan diperjanjikan" (pasal 8 ayat (1))

"Kredit atau pembiayaan berdasarkan prinsip syari'ah yang diberikan bank mengandung resiko, sehingga dalam pelaksanaannya bank harus memperhatikan asas-asas perkreditan atau pembiayaan berdarkan prinsip syari'ah yang sehat. Untuk mengurangi resiko tersebut, jaminan pemberian kredit atau pembiayaan berdasarkan prinsip syari'ah dalam arti keyakinan atas kesanggupan nasabah debitur untuk melunasi kewajibannya sesuai dengan yang diperjanjikan merupakan faktor penting yang harus diperhatikan bank. Untuk memperoleh keyakinan tersebut, sebelum memberikan kredit, bank harus melakukan penilaian yang seksama terhadap watak, kemampuan, modal, agunan, dan prospek usaha dari Nasabah Debitur. Mengingat bahwa agunan sebagai salab satu unsur pemberian kredit, maka apabila berdasarkan unsur-unsur lain telah dapat diperoleh keyakinan atas kemampuan Nasabah Debitur mengembalikan utangnya, agunan dapat hanya berupa barang, proyek atau hak tagih yang dibiayai dengan kredit yang bersangkutan. Tanah...” (penjelasanpasal 8 ayat (1))

"Bank Umum dapat membeli sebagian atau seluruh agunan, baik melalui pelelangan maupun di luar pelelangan berdasarkan penyerahan secara sukarela oleh pemilik agunan atau berdasarkan kuasa untuk menjual di luar lelang dari pemilik agunan dalam Nasabah Debitur tidak memenuhi kewajibannya kepada bank, dengan ketentuan agunan yang dibeli tersebut wajib dicairkan secepatnya (psl.12-a(1))

Dalam Peraturan Bank Indonesia (PBI) No. 5/7/PBI/2003 tentang kaualitas Aktiva Produktif Bagi Bank Syari'ah pasal 2 (ayat 1) dan penjelasannya, dan pada PAPSI (Pedoman Akuntansi Perhankan Syari'ah Indonesia) tahun 2003 Bank Indonesia:

Penanaman dana Bank Syariah pada Aktiva Produktif wajib dilaksanakan berdasarkan prinsip kehati-hatian. (Pasal 2 (ayat 1)). Yang dimaksud dengan prinsip kehati-hatian dalam penanaman dana yaitu penanaman dana dilakukan antara lain berdasarkan:1). Analisis kelayakan usaha dengan memperhatikan sekurang-kurangnya faktor 5C (Character, Capital, Capacity, Condition ofeconomy \& Collateral); 2). Penilaian terhadap aspek prospek usaha, kondisi keuangan dan kemampuan memhayar. (Penjelasan Pasal 2). 
"Pada prinsipnya dalam pembiayaan mudharabah tidak dipersyaratkan adanya jaminan, namun agar tidak terjadi moral hazard berupa penyimpangan oleh pengelola dana, pemilik dana dapat meminta jaminan dari pengelola dana atau pihak ketiga. Jaminan ini hanya dapat dicairkan apabila pengelola dana terbukti melakukan pelanggaran terhadap hal-hal yang telah disepakati bersama dalam akad" (PAPSI 2003, h. 58).

b. Dalam KUH Perdata pasal 1131 dan pasal 1132 berikut ini:

"Segala kebendaan si berutang, baik yang bergerak maupun yang tidak bergerak, baik yang sudah ada maupun yang baru ada di kemudian hari, menjadi tanggungan untuk segala perikatannya perseorangan." (pasal 1131)

Kebendaan tersebut menjadi jaminan bersama-sama bagi semua orang yang mengutangkan padanya; pendapatan penjualan bendabenda itu dibagi bagi menurut keseimbangan yaitu menurut besarkecilnya piutang masing-masing kecuali apabila di antara para berpiutang itu ada alasan-alasan yang sah untuk didahulukan. (pasal 1132)

\section{Jaminan Dalam Pembiayaan Mudharabah}

Mudharabah adalah akad kerjasama antara pemilik modal (shahibul maal) untuk menyertakan modalnya kepada pekerja (pengusaha) untuk diinvestasikan, sedangkan keuntungan yang diperoleh menjadi milik bersama dan dibagi berdasarkan kesepakatan bersama. $^{11}$

Dalam konteks perbankan, pembiayaan mudharabah adalah akad kerjasama usaha antara bank sebagai pemilik dana (shahibul maal) dan nasabah sebagai pengelola dana (mudharib) untuk melakukan kegiatan usaha dengan nisbah pembagian hasil (keuntungan atau kerugian, profit and loss sharing) menurut kesepakatan di muka. Dalam pembiayaan mudharabah hubungan antara pihak bank dengan dengan pihak nasabah pengelola dana didasarkan pada prinsip kepercayaan (amanah), maksudnya pengelola dana (mudharib) dipercaya untuk mengelola modal mudharabah, dia tidak dikenakan ganti rugi (dhaman) atas kerusakan, kemusnahan, atau kerugian yang menimpanya selama tidak disebabkan atas kelalaian, kecerobohan, atau tindakannya yang melanggar syarat dalam perjanjian. ${ }^{12}$ Karena kepercayaan merupakan prinsip terpenting dalam transaksi pembiayaan mudharabah, maka

\footnotetext{
${ }^{11}$ As Sarakhsi, , Jilid XXII., h. 18.

12 Al-Kasani, jilid. 8, h. 360.
} 
mudharabah dalam istilah bahasa inggris disebut trust financing atau trust investment. Prinsip inilah yang membedakan pembiayaan yang menggunakan akad mudharabah dengan akad-akad lainnya.

Atas dasar prinsip di atas, pihak pemilik modal (shahibul mat) pada prinsipnya tidak dapat menuntut jaminan apapun dari mudharib untuk mengembalikan modal atau modal dengan keuntungan. Jika pihak shahibul mal mempersyaratkan pemberian jaminan dari nasabah pengelola (mudharib) dan menyatakan hal ini dalam syarat kontrak, maka kontrak mudharabah tersebut menurut mayoritas ulama (jumhur ulama) tidak sah (ghair shahih) karena bertentangan dengan prinsip dasar akad "amanah" dalam mudharabah. ${ }^{13}$

Meskipun fiqih tidak mengizinkan pemilik modal/investor untuk menuntut jaminan dari mudharib, dalam kenyataannya, bank-bank Islam umumnya benar-benar meminta beragam bentuk 'aminan, baik dari mudharib sendiri maupun dari pihak ketiga. Xamun mereka menegaskan bahwa jaminan tidak dibuat untuk memastikan kembalinya modal, tetapi untuk memastikan bahwa kinerja mudharib sesuai dengan syarat-syarat kontrak. International Islamic Bank for Investment and Development, misalnya, mempersyaratkan bagi pemohon pendanaan mudharabah untuk menyatakan jenis jaminan yang dapat mereka berikan kepada bank. Demikian juga, salah satu klausul dalam kontrak mudharabah pada Faisal Islamic Bank of Egypt dinyatakan bahwa"jika terbukti bahwa mudharib menyalahgunakan atau tidak sungguhsungguh melindungi barang-barang atau dana-dana, atau bertindak bertentangan dengan syarat-syarat investor, maka mudharib harus menanggung kerugian, dan harus memberikan jaminan sebagai pengganti kerugian semacam ini." ${ }^{14}$ Di Indonesia, sebagaimana yang telah diuraikan di atas, praktik oengenaan jaminan untuk pembiayaan mudharabah sah adanya baik Derdasarkan UU No. 10 tahun 1998 tentang perbankan maupun menurut peraturan Bank Indonesia. Bahkan Majelis Ulama melalui lembaga Dewan Syari'ah Nasional (DSN) juga membolehkan praktik $\cdot$ aminan tersebut. ${ }^{15}$

${ }^{13}$ Ini merupakan pendapat madzhab Hanafi, Maliki, Syafi'i, dan Hambali. Lihat Ibn Qudamah, op. cit, jilid. 5, h. 129, al-Kasani, op. cit, Jilid 7, h. 360, asySyarbaini, Mughni al-Mukhtaj, op. cit., jilid. 2, h. 317.

${ }^{14}$ Abdullah Saeed, Islamic Banking and Interest: a Study of Riba And Its Contemporary Interpretation, Arif maftuhin (penerjemah), Menyoal Bank Syari'ah, Jakarta: Paramadina, 2004, Cet. 2, h. 86

${ }^{15}$ Fatwa DSN No. 07/DSN-MUI/IV/2000. Ichwan Syam dkk, Hpunan Fatwa Dewan Syari'ah Nasional, Jakarta: DSN-MUI dan BI, 2003, Cet. 2, h. 45 
Berangkat dari fenomena di atas, dapat disimpulkan bahwa ada perbedaan antara konsep mudharabah dalam fiqh klasik, dengan aplikasinya di perbankan syari'ah, di antaranya mengenai persoalan jaminan yang harus diberikan mudharib kepada pihak shahibul mal dalam hal ini bank syari'ah. Menyikapi persoalan ini, para ahli hukum Islam kontemporer, di antaranya adalah Muhammad Abdul Mun'im Abu Zaid dalam bukunya Nahwa Tathwiri Nidhami al-Mudharabah ft al-Masharif al-Islamiyah, ${ }^{16}$ menyatakan bahwa jaminan untuk pembiayaan mudharabah dalam praktik perbankan syari 'ah diperbolehkan dan sangat penting keberadaannya atas dasar 2 (dua) alasan berikut ini: pertama, pada konteks perbankan syari'ah saat ini mudharabah yang dilakukan berbeda dengan mudharabah tradisional (mudharabah tsunaiyah) yang hanya melibatkan dua pihak shahibul mal dan mudharib, di mana keduanya sudah saling bertemu secara langung (mubasyarah) dan mengenal satu dengan lainnya. Sementara praktik mudharabah di perbankan syari'ah saat ini, Bank berfungsi sebagai lembaga intermediary memudharabahkan dana shahibul mal yang jumlahnya banyak kepada mudharib lain, dan shahibul maal yang jumlahnya banyak tersebut tidak bertemu langsung dengan mudharib sehingga mereka tidak bisa mengetahui dengan pasti kredibilitas dan kapabilitas mudharib. Oleh karena itu, untuk menjaga kepercayaan dari nasabah investor, bank syari'ah harus menerapkan asas prudential, di antaranya dengan mengenakan jaminan kepada nasabah penerima pembiayaan.

Kedua, situasi dan kondisi masyarakat saat ini telah berubah dalam hal komitmen terhadap nilai-nilai akhlak yang luhur, seperti kepercayaan (trust) dan kejujuran. Berkaitan dengan hal ini, Abdul Mun'im Abu Zaid dalam karyanya yang lain "Al-Dhaman fi al-Fiqh alIslamy" juga menyatakan bahwa faktor terbesar yang menjadi hambatan perkembangan Perbankan Syari'ah, khususnya dalam bidang investasi adalah rendahnya moralitas para nasabah penerima dana pembiayaan dalam hal kejujuran (al-shidq) dan memegang amanah (alamanah). ${ }^{17}$ Oleh sebab itu, larangan jaminan dalam mudharabah karena bertentangan dengan prinsip dasarnya yang bersifat amanah bisa berubah karena adanya perubahan kondisi obyektif masyarakat dalam

\footnotetext{
${ }^{16}$ Muhammad Abdul Mun'im Abu Zaid, Nahwa Tathwiri Nidbami alMudharabah fi al-Masharif'al-Islamiyah, Mesir: al-Ma'had al-Alamy li al-Fikr alIslamy, 2000, h. 127-128

${ }^{17}$ Muhammad Abdul Mun'im Abu Zaid, Al-Dhaman fi al-Fiqh al-Islamy wa Tathbiqatuhu fi al-Masharif al-Islamiyah, (Mesir: al-Ma'had al-Alamy li al-Fikr alIslamy, 1996), cet. 1, h. 74
} 
bidang moralitas. sesuai dengan kaidah al hukmu yaduru ma'a illat wujudan wa 'adaman. Artinya: Keberadaan hukum ditentukan oleh ada atau tidaknya 'illat (alasan). Jika 'Ilat berubah maka akibat hukumnya pun berubah.

Namun demikian, meskipun jaminan dalam mudharabah dalam praktik perbankan saat ini diperbolehkan, tetapi disyaratkan bahwa jaminan tersebut harus didasarkan pada tujuan menjaga agar tidak terjadi moral hazard berupa penyimpangan oleh pengelola dana (taqshir al-amiil), bukan bertujuan untuk mengembalikan modal bank atau sebagai ganti rugi (dhaman) setiap kerugian atas kegagalan usaha mudharib secara mutlak. ${ }^{18}$ Oleh karena itu, jaminan hanya dapat dicairkan apabila pengelola dana terbukti melakukan pelanggaran (ta'addi), kelalaian (taqshir), atau menyalahi kesepakatan yang telah ditentukan (mukhalafatu al syurut). ${ }^{19}$ Di samping itu, kewajiban adanya jaminan dalam mudharabah tidak harus dibebankan kepada mudharib tetapi bank dapat meminta jaminan kepada pihak ketiga yang akan menjamin mudharib bila melakukan kesalahan. ${ }^{20}$ Dalam konsep fiqh jaminan oleh pihak ketiga dikenal dengan akad kafalah sebagaimana yang telah dibahas sebelumnya.

\section{Kesimpulan}

Dari uraian tentang penerapan hukum jaminan dalam pembiayaan di perbankan syari'ah di atas, dapat disimpulkan beberapa hal sebagai berikut:

1. Urgensi jaminan dalam hukum Islam di kenal dengan dua istilah, yaitu kafalah dan rahn. Untuk jaminan yang diberikan oleh pihak lain atas kewajiban/prestasi yang harus dilaksanakan oleh pihak yang dijamin (debitur) kepada pihak yang berhak menerima pemenuhan kewajiban/prestasi (kreditur) disebut dengan kafalah. Sedangkan jaminan yang terkait dengan benda/harta yang harus diberikan debitur (orang yang berhutang) kepada kreditur (orang yang berpiutang) disebut dengan rahn.

\footnotetext{
${ }^{18}$ Ibid, h. 49

${ }^{19}$ Menurut PAPSI (Pedoman Akuntansi Perbankan Syari'ah Indonesia) tahun 2003 Bank Indonesia, bentuk-bentuk kelalaian atau kesalahan pengelola dana (mudharib), ditunjukkan oleh: 1). Tidak dipenuhinya persyaratan yang ditentukan dalam akad, 2). Tidak terdapat kondisi di luar kemampuan (force majeur) yang lazim/atau yang telah ditentukan di dalam akad, atau 3). Hasil putusan dari badan arbitrase atau pengadilan.

20 Ibid.
} 
2. Keberadaan jaminan dalam produk pembiayaan di perbankan syari'ah sebagaimana perbankan konvensional sangat penting mengingat bank merupakan lembaga intermediary yang menerima "amanat finansial" dari para nasabahnya. Dalam kaitan ini jaminan merupakan wujud dari kehati-hatian (prudential) bank dalam mengelola dana dari para nasabahnya.

3. Jaminan dalam pembiayaan yang menggunakan skim mudharabah menurut kesepakatan para ulama klasik adalah dilarang dan menyebabkan tidak sahnya akad karena bertentangan dengan prinsip "amanah" yang mendasari akad ini. Akan tetapi, sebagian ulama kontemporer dan berdasarkan aplikasi di perbankan syari'ah saat ini, jaminan dalam pembiayaan mudharabah diperbolehkan tetapi bukan dimaksudkan untuk memastikan kembalinya modal, melainkan untuk memastikan bahwa kinerja mudharib sesuai dengan syarat-syarat kontrak dan untuk menjaga agar tidak terjadi moral hazard berupa penyimpangan oleh pengelola dana (taqshir al-amiil). Oleh karena itu, jaminan hanya dapat dicairkan apabila pengelola dana terbukti melakukan pelanggaran ( $t a$ 'addi), kelalaian (taqshir), atau menyalahi kesepakatan yang telah ditentukan (mukhalafatu al-syurut).

\section{Daftar Pustaka}

Abidin, Ibnu, Radd al-Muhktar ala ad-Durr al-Mukhtar, Jilid V (Beirut: Dar al-Fikr), 1963

As Sarakhsi, alMabsut, Beirut: Dar al Fikr, tt., Jilid XXI, tt.

Ad-Dardir, Syarh al-Shagir hi Syarh ash-Shawi, Mesir : Dar al-Fikr, Jilid III, 1978

Asy-Syarbaini al-Khatib, Mughni al-Muhtaj, Beirut: Dar al-Fikr, Jilid II, 1994

Ibn Rusyd, Bidayatul Mujtahid Wa Nihayatul Muqtashid, Indonesia: Dar al-Ihya', tt.

Jumhana. Muhammad, Hukum Perbankan di Indonesia, Bandung: PT. Citra Aditiya Bakti, 2000

M. Bahsan, Penilaian Jaminan Kredit Perbankan Indonesia, Jakarta: CV. Rejeki Agung, 2002 
Muhammad Abdul Mun'im Abu Zaid, Al-Dhamanfi al-Fiqh al-Islamy wa Tathbiqatuhu fi al-Masharif al-Islamiyah, Mesir: al-Ma'had al-Alamy li al-Fikr al-Islamy, 2006

Muhammad Abdul Mun'im Abu Zaid, Nahwa Tathwiri Nidhami alMudharabah fi al-Masharif al-Islamiyah, Mesir: al-Ma'had alAlamy li al-Fikr al-Islamy, 2000

Saeed. Abdullah, Islamic Banking and Interest: a Study of Riba And Its Contemporary Interpretation, Arif maftuhin (penerjemah), Menyoal Bank Syari'ah, Jakarta: Paramadina, 2004

Salim HS, Perkemhangan Hukum Jaminan di Indonesia, Jakarta: Rajawali Press, cet. 1, 2004

PAPSI (Pedoman Akuntansi Perbankan Syari'ah Indonesia) tahun 2003 Bank Indonesia

Tim Bank Syari'ah Mandiri, Apa dan Bagaimana Bank Syari'ah, Jakarta: BSM Cab. Meruya, 2005

Zuhaili. Wahbah, Al-Fiqh al-Islamy wa Adillatuhu, Beirut: Dar al-Fikr, Jilid. 6, 2002 